\title{
From De Jure to De Facto. The Armistice Treaty and Redefining the Role of the United Nations in the Korean Conflict
}

\author{
JUNC-HOON LEL:

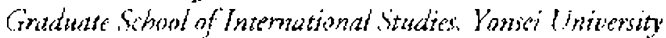

\begin{abstract}
North Korea has Long sried wo undermine the Amwitice Treaty of 1953 in order to replace it with a comprehensine peact treaty with the Cnited States. With Nonh Korea closing its temitory to members of the Neutral Nations Superizory Commission (NNSC) in 1995, the debute ane the praticubility of the Military Amistice Treaty bas been rekindled in recent years. In a brouder sense, at issue is the effectivenes: of the United Nations Command in continuing to maintain peace. on the Korean peninsula. How functional bas the armistice treaty: been in whoring its reles: In what ways does the armistict treaty affect the inter-Korean ritutionship?. To what extent would a U.S.-North Kowa peaie treary compromise the positions of the Cinited Nations Command and the U.S. armed forces in Soush Korea? Keeping in mind these and other questions, this article examines first, the challenges facing the UN $\mathrm{N}$ sonsored amistice apparatus, and second, bow the imolved partic's - South Korea in particular -- rnay cope with these challonges to ensure permanent security in Korea. This aricle saggests that South Korta should propose to rezive the principles raised in the Genen Conference of 1954, especially concerning the need for the recognition of the United Nations' authority and competence to deal with the Koran affirir. With the Cold Whr ended, the Conference stands a far better chance to survive and perhaps to resolve the Korean question onie and for all. Further to this argument the article proposes

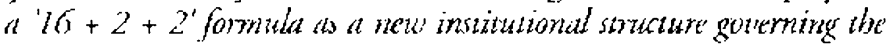
secterity issues on the Korean penizusula. Although the idea is still forrmative, it is argued that if the United States, South Korea, and the IN phay their respective cards right, the pmposed aryangement may stand as good a chance as any in resolving the Korean question, especially from a South Komean vantage point.
\end{abstract}

\footnotetext{
* Prepared uriginaliy tor the Internacional Symposium on "The Urited Nations: Bemeen Sovereignoy and Global

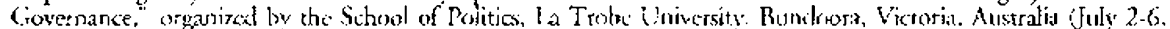
1997). Direct all correspondence ko lungttfon lec, Assistant l'rofessor. (iratuate School of Inremational Srudies.

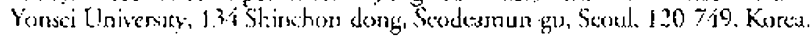


Torth Korea's decision on May 3, 1995, to dose its territory to members of the 1 Neutral Nations Supervisory Commission (NNSC), in effect unilaterally implying an end to the armistice supervisory body in Korea, has rekindled the debate over the practicability of the Military Atmistice Treaty (MAT) of 1953. In a broadcr scnse, also at issue is the effectiveness of the Inited Nations Command in continuing to maintain peace on the Korean peninsula. Coming on the heels of the Bosnian crisis that had the effect of raising questions about the ability of the post-Cold War UN peacekeeping operations, the U.N's role in the 'armistice debate' in South Korea has also been under fire in the wake of North Korea's attempts to undercut the armistice agreement. The main concen over North Korca's marginalization of the armistice pact has to do with its open intention to replace in with a peare creaty wish the United States. If sucecssful, it could throw off the political-military balance that has hitherto ensured security in this last bastion of the Cold War confrontation.

How functional has the armistice treaty been in enforcing its rules? In what ways does the armistice treaty affect the inter-Korean relationship? To what extent would a U.S.North Kored pacate treaty conpromise she positions of the United Nations Command and the I'S. armed forces in South Korea? Keping is mind these and other questions, this arricle examines first, the challenges facing the UN $\mathrm{N}$-sponsored armistice apparatus, and second, how the involved parties-South Korea in particulas-m may cope with these challenges to ensure permanent security in Korea.

\section{THE KOREAN CONFLICT AND THE UNITED NATIONS}

The Unired Nations' relationship with Korea dates back to 1948 when the LN Temporary Commission on Korea (UNTCOK) supervised general elections in the South, ultimately leading to the creation of the Republic of Korea (ROK). 'But the foundation for the current UN-South Korea relationship was laid when the UN Security Council adopted a resolution on June 27,1950 calling for members of the United Nations to "repel North Korean armed attack" of South Korean positions below the 38 th parallel and to "restote international peace and security in the area." "Facilitating assistance in defence of the $\mathrm{ROK}$ required operarional coordination. To this end, another resolution was adopted on July 7,1950 requesting contributing nations to place thamselves under a unified command-the UN Command-headed by the United States, with General Douglas MacArthur serving as its tirst Commander-in-Chief. Although for-

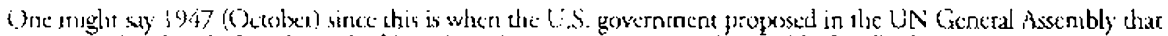
eleccions aake place befort the end of March 1948 to trace a national assembly for all of Korea. Br. this time, in

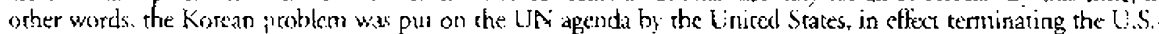

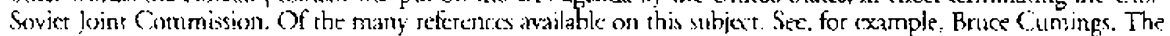

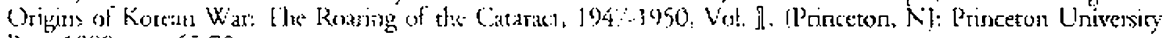

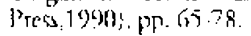

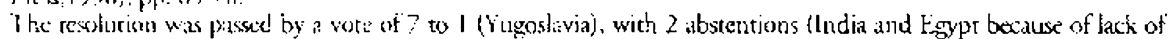

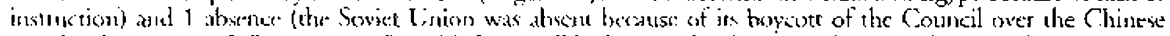

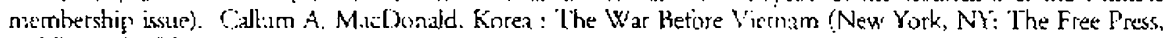
$1986,2.3032$. 
mally under the LN flag, the United States as such canse to dominate all military operations of the Korean conflict."

By Ocuber 1950, the IN forces, having aken the offensive since landing in Inction in Seprember, noc only regained the rerritory of the ROK, but more importantly, crossed the 38 th parallel so advance into North Kored. It was never the UN's formal war aim to reunify che country. But the resulution of October 7 establishing the UN Conmission for the Unification and Rehabilitation of Korea (UNCURK), calling for the establishmen of a unified, independen and democraric government in the sovereign state of Korea," implicitly suggested suct a goal. Cenerad MacArthur took the libery to magnify this puine in order to legitunize his march towird the Yalu River."

Oric of the unfortunate outcomes of the "expansion" of the UN goal was the Communist Chinese intervention. This decision would ultimately cost the Chinese dearly-w over 900,000 asualties among the Chinese People's Volunters (CPVs), continued denial of its UN membership, over $\$ 2$ billion debt to Moscow and the non-fulfillment of "Lawan's "liberation" -- but it alsu changed quite drastically the spectrum of the Korcan Conflici."

In particular. MacArthur's inability to understand more filly Beijing's fear of being encircled by what it considered to be hostile U.S.-led imperialist forces prompted a "detensive" response." Despire the efforts in November by some of the members of the Security Coumil to assure the Chinese of the LIN policy to hold "inviolate" the Chinese frontier, the dreaded prospect of the conflict being spread was now irreversible. The consequent UN tetrat would be followed by a stakmate by the summer of 1951 roughly along the 38 th patrall 1 .

From June 1951 to July 1453 negotiations for an armistice were conducted herween the UN Commmand on the one band and the Communist Command on the other. Contral to the talks were:

1.) the drawing of the denzatcation line;

2) the prevertion of a mithay buildup in eidher side; and

$3 i$ the privonces-ot-was exchange mechanism based on intertational law and humanitarian principles.

In all, the ammistice negotiations lasted more than wo years, requiring some 575 meet-

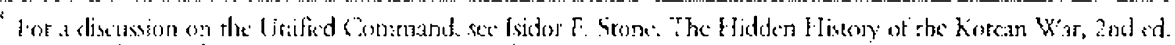

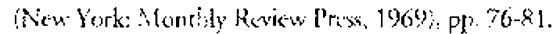

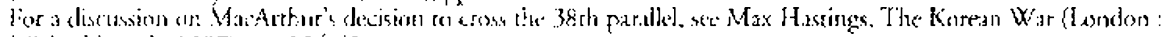

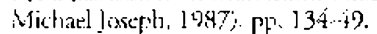

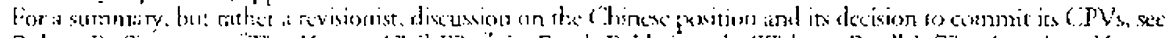

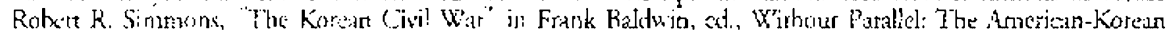

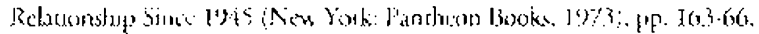

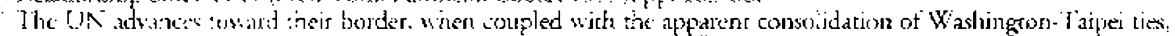

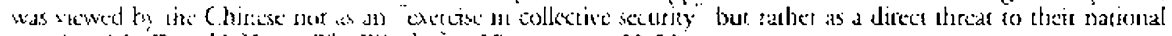

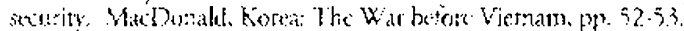

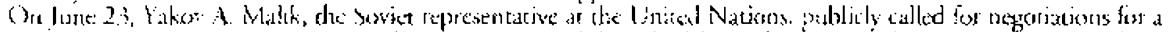

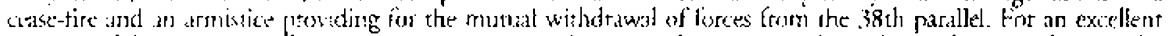

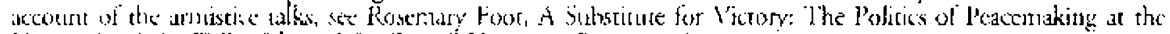

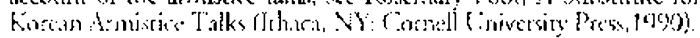


ings before a settlement could be reached. But while the negotiations were being conducted, fighting continued to claim some 45 percent of American casualties during this period. "1he numbers were even more staggering for the more vulnerablc Communist side. When the armistice agreement was finally signed at Panmunjom on July 27, 1953 , it ended the costly war, but it fell short of creating a lasting peace as had been hoped for by the IN Command. The agreement did, nonerheless, provide tor a cease-fire, a demilitarized zone, a military demarcation line, and a ban on reinforcements. And in order to supervise the armistice, a Military Amistice Commission ( $\mathrm{MAC}$ ), composed of representatives of the two belligerent sides, was established. The Neutral Nations Supervisory Commission (NNSC) was also established to see to each side's compliance with the specific terms concerning the tan on reinforcements [Armistice Agreement: Paragraph 13(c)]. The NNSC was comprised of representatives from Sweden, Switzeriand, Ioland. and Caechoslovakia - nations that had not particjpated in the war, and therefore, considered to be 'impartial.' But Sweden and Switzerland having been appointed by the UN Command, and Poland and Czechoslovakia by the Supreme Commander of the Korean People's Army and the Commander of the Chinese People's Volunters, the question of 'incutrality' was always in doubt.

The Military Armistice Treaty did not end the war. Nor did it provide for a final peace settlement. Paragraph 60) of the agreement did recommend that a political conference be held soon to negotiate a peaceful settlement of the Korean question, but no concrete provisions were laid down as to how this was to be done. The armistice agreement was in essence an instrument to stop the belligerency, albeit temporarily, while providing for an arms control mediantsm. The UN Conmand, in other words, had hoped to freeze, with the NNSC. in charge of the verification, the arrss kevel in both North and South Kored, thus facilitating a peace talk at some furure rime. It is this tather unsealistic aspecr of the MAT that has spurred the recent debate over the usefulness of this forty-two year old agreement.

Advocates of the arreement argue thar, irrespective of its weaknesses, it still remains the only arailable instrument that oversecs the process of maincaining peace in Korea." As the argument goes, the need to govern the state of armistice legitimizes the continuing presence of the (IN Command in Korea. i.c., the U.S. forces, which is still deemed critical co rhe peninsular securiry. On the other side of the spectrum, antagonists argue for the anmulment of the MAT not only because of its ineffectiveness, but also as a step to check North Korea's attempts to use it to exclude South Korea in the negotiations for a comprehensive peate treaty, that is with the United States." "Then there is the revisionist argument, which also calls for an end to the anmistice agreement, but for an entircly different reason: its hindrance of a genuine North-Sonth reconciliation by perpetuating the U.S.

\footnotetext{
Ihid. p. 208 .

For an exanple of an advexate's argument, sec Richasd M. Curasi, "The Kincean War Armistice: Relevant or

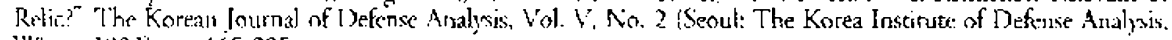
Winter 2493). pp. 165-205.

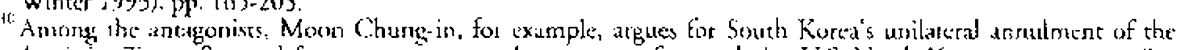
Asnusice Treary frst and foremost to pevent the prospect of an exclusive U.S.-North Korea peace steaty. Sec Vion:s arguments in Sisa joumak, june 8, 1995 . Pp. $54-55$
} 
military presence in Korea."

Although goaded by the Cold War-conscious United States, the decision ro intervene in the Korean conflic has inextricably intertwined the United Nations with the future security of Korea. Because the armistice, technically speaking, only suspended the military operations, the United Nations has endeavoured ever the years to bring about a final resolurion to the conflict by peactiul means. The lapsed time since the ending of the war has fundamentally altered the socio-political make-up of the rwo Koreas. But the two remain locked in a hostile confrontation, with neither side showing genuine signs of relenting. Against this background, the fact that the armistice is maintained by a weak governing structure, that of the Military Armistice Commission, has been pointed out as a source adding to Korea's inscourity. But the guestion rematins as to how one might go about finding a vable alremative to the arnistice tedey without compromising South Korea s security position? As concerns the Uniced Nations, to what extent is it responsible for and capable of bringing about the necessary change?

Having briefly traced the origins of $U N-R O K$ relationship in this section, this article will serurn to the above questions following a discussion on North Korea's recent elforts to dismiss the armistice agrement and how this has highlighted the issue at stakc.

\section{NORTH KOREA AND THE ARMISTICE CONUNDRUM}

North Korea's call for a peace treaty berween Washington and Pyongyang to replace the armistice agrecment of 1953 is not now. In fact, North Koreans have consistently made demands on this matter for the past wo docades. What makes Pyongyang's pitch in the 1990 s unique, therefore, is the way the issue bas been tied to the successful implemencarion of the landmark nuclear agreement signed in Geneva on 21 Ocroter 1994. It is no secrec that carlier nuclcar brinkmanship as exercised by the North Koreans has paid handsome dividends." As such, Pyongyang's "no peace treaty; no nuclear deal" threar can be regarded as an extension of iu brinkmanship, well in keeping with its long-held policy objective of detaching Souch Korea from the Lnited States by somchow bringing about the withdrawal of U.S. troops from South Korea. It is assumed, in the main by tle North Korans themsclves, that an exclusive C.S.-North Korean peace treaty would bring about just such results, potentially leaving South Korea vulnerable to North Korea's political, and to a lesser extent military, influence. ${ }^{13}$ This is doubtess the single most impor-

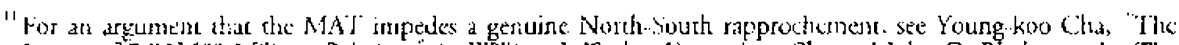

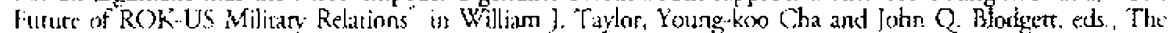

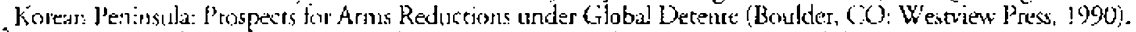

${ }^{12}$ For apreting on frecze and evencually dismantle its suspected homb-makiug capability. North Korea gets nwo light-

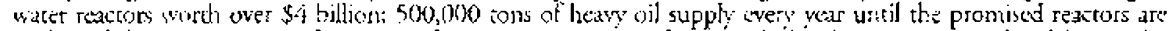

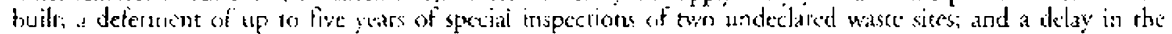

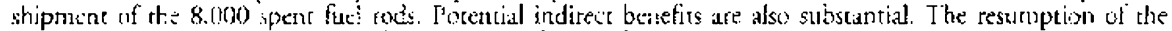

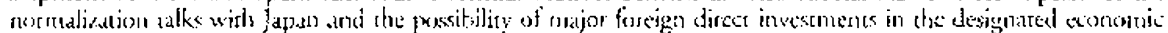
develofment wones ate turo of the must salient examples.

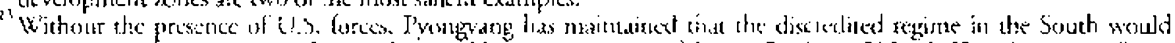

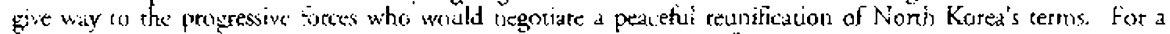

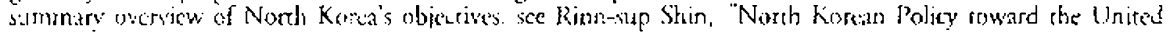


tant reason why Pyongyang has been so active in trying to nullify the armistice agreement while calling for a peace rreaty to replace it. With a direct channel of communication with Washington established in the midst of the nuclear talks, Pyongyang's push for the removal of the armistice treaty thus gained momentum since 1994. For example, this matter has been under discussion formally as part of the four-party talks set up on 16 April 1996.

If there is one explanation for North Korea's cavalier treatment of the armistice agreement, it is the lack of a consensus in the way the purpose of this agreement has been regarded. i'he UN Command saw it as a step toward an eventual peace settlement. The Communsts, on the other hand, saw it more as a temporary measure chat would allow them to regroup to prepare for an ulcimate socialist victory. As such, the Communists-particularly the North Koreans-- found it unnecessary to make a genuine commitment to honour the provisions of the agreement.

Against this backdrop, it is easy to see why the Military Armistice Commission failed to be effecrive from the moment it came into force. Morcover, the monitoring mechanism, which was the NNSC, was rendered dysfunctional because of the superpower confrontation. "I'he NNSC was initially furnished with both fixed and mobile inspection toams, but lacking the nocessary Icverage to cnforce verification, it was by 1956 reduced ro a token presence at Panmunjom. I'erfunctory mectings were still held, but they were mere formality, neither constructive nor productive.

The coinciding of the disintegtation of the Soviet Union and the launching of South Korea's Nordpolitik in the late 1980s further chipped away at the viability of the NNSC. This was because the two "neutral" nations appointed by the Communist CommandPoland and Cizechoslowakia-came to normalize their diplomatic relations with South Kotea in 1989 and 1990, tespectively. North Koted protested these devclopments, eventually leading to the exputsion in April 1993 of the new (Zech representative who tried to take up residence in the North Korean zone of the truce village following the breakup of Czechoslovakia into the Czech Republic and Slovakia in lanuaty 1993. "in February 1995, Poland, too, was evicted from the NNSC, for having abandoned its "neutral" posirion 1

North Korea, on its part, has boycotted the MAC. meetings since March 1991 when a South Koreat Army Major General. Hwang Won-tak, was appointed the new chief UNC representative to the MAC. Citing South Korea's non-signatory status to the armistice agreement, North Korea has claimed the U.S.-sponsored appointment to be in violation of the principles of the agreement. To make its point more emphatic, North Korea on 28 April 1994 announced its decision to withdraw entirely from the MAC. The provisions of the armistice agreenent were to be honoured. however, antil it was replaced by a peace treaty with the United Stazes. On. August 31, 1994, China followed

Stares: Pass and Furure in Bum Joon lee and Sung C'nul Yang, eds.. The Changing W'ould Order: l'rospects for

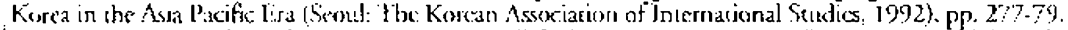

'.i For some accounts of North Kotea's moves to nullify the atmistice pact, sce 'the Korea Herald, March 19. 1995;

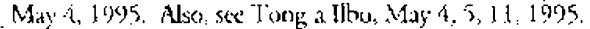

"North Kores itricized l'oland for atyandoning her neutrality not only by normalizirng rciations with Sourt Korea, but alu by acnding observers to the L.S.-ROK Then Spirit milicary extreise. 
North Korea's suit by recalling its own representatives to the MAC. Now left as the only parry represented in the $\mathrm{MAC}$, the INC, promptly moved to stop any further erosion of the MAC by reconfirming its commiment to the terms of the armistice agreement. As pointed out by onc UNC official: "UNC' will continue to honor the armistice agreenent and each obligation under the agreement."

For better or for worse. North Korea las a be credited for its persistence and consistency. In yet another atrempt to dismantle the armistice agreement. North Korea, in a MAC meeting hald on 3 May 1995, called on the Swedish and Swiss delegations to withdraw from North Korean sections in the Panmunjom Joint Security Area." "lo cross the demarcarion line now required North Korea's permission. Methodically, if not meticu-

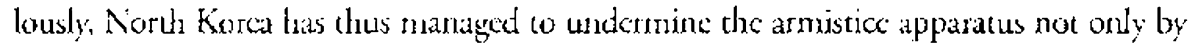
pulling our the Conmunist Command (North Korea and (hin:s) from the MAC, bur also by either evicting of distupting the operations of all four members of the NNSC. With the United States remaining the only constant in the amistice structure, North Korea has thus quite deftly set the stage to deal with the United Stares alone, presumably having deared most of the barricrs arising from the armistice structure.

The link between Vouth Korea's attempts to undernine the amistice agreement and its intention to conclude a peace treaty with the United States, without Secul's participation, is an open secret. Since its agreement with the United States in Kuala I umpur accepting a technical description, which indirecrly refered to a reactor model of South Korcan origin -. Ulchin plants 3 and 4 North Korea has tried to get the Uniced States to reciprocate what the North Koreans considered to be a major "compromise" on their position." In the immediate sense, at issue was the establishment of liaison offices in I'yongrang and Washington. Also at issuc, at least carlier, was the possibility of a generallevel mecting just berween the two countries to work out a new security system on the Korean peninsular. If successful. this would have been a prelude to a more comprehensive political settement, teplacing the current annistice setup as a result."

The U.VC has so far countered that any such meering should take on a multilateral approach, well reffective of the UNC: structure. The conventional thinking is that any form of a peace treaty would involve the widhdrawal of all foreign troops in Koreameaning the 37,000 U.S. troops in 5onth Korea. What North Korea might do text once this is realized is still uncertain. It is safe to surmise simply that North Korea will have: obrained onc of its most important, long-held national goals, which is to facilitate a genuine reuniticarion process, or rather, the "liberation" of the South. If the Geneva and the Kuala Lumpu agrements were an indication of further things to come, North Korea at

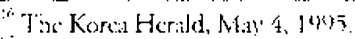

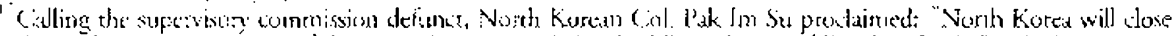

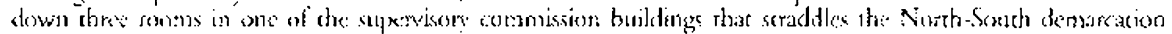

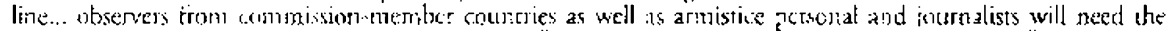

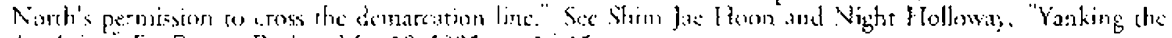

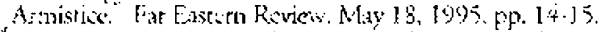

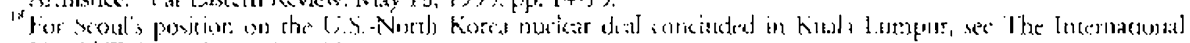

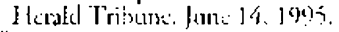

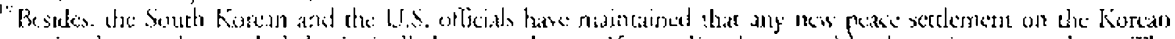

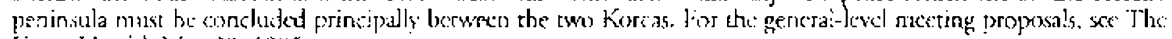
Kurcalterail. Mar 23, 1945.
} 
the time must have felt quite good about its position. Above all, the fact that it could reach a series of agreements with the United States without having to make any progress in North-Souch relarions, and to reduce at least the perception of its threat to South Korea, was indeed encouraging for North Korea. By-passing Sourh Korea while pursuing formal ties with the United States and Japan has since become a viable policy option for Pyongyang.

'The United States' cuntinued dependence on Pyongyang's goodwill to implement successtiuly the utuclear deal also had the effect of strengthening North Korea s position. For Seoul, of course, this is precisely what it fears the most: the prospect of South Korea becoming a bystander to developments that have direct inplications for its own national security.

\section{THE ARMISTICE, THE UNC, AND POLICY OPTIONS FOR SOU'TH KOREA}

Nobody knows North Korea's 'peace treaty for amistice' scenario better than Sourh Korea. 'This is why South Korea's apparent alicnation has becn so frustrating, knowing that it has litde control over affairs that may not necessarily bode well for its future security. The picture of North Korea often being a step ahead of its L.S. counterpart in setting the negotiations agenda is particularly alarming for South Korea. The United States of course bas its own interests in wanting to see through the North Korean nucleat dilcnma:

1.) its link to the extension of the NI'T regimc;

2) a much-needed diplomatic achievement for the Clinton administration: and

3) the possibilicy of establishing a foothold in the cntire Korean peninsula, a prospect which might be desirable if the United States accepts the inevitability of hegemonic power struggle in Last Asia in the long-run. One might say that North Korea has been very successful in recognizing and exploixing the United Stales' agerness to bring such interests into fruition.

But how did Souch Kotea, still enjoying a firm relationship with the Inited States, come to be squeezed out by North Korea on this critical issue? Is it simply the case of South Korea nor having appropriate leverage? A quick answer to the first question is diplonacy, or the lack of it, and to the second, an emphatic ' $N o$ '. 'The two questions are in a sense interrelated. In other words, South Kored's inability to make full use of the only keverage it had at its disposal has consequently led to its subsequent state of diplomatic hankraptcy. 'The leverage hete refers to the South Korean capital that is expected to finance the construction of the light-water reactors in the North. Considering that no other country-inclusive of the Lnited Srates and Japan- had expressed willingness to

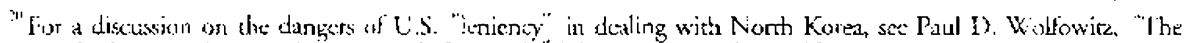

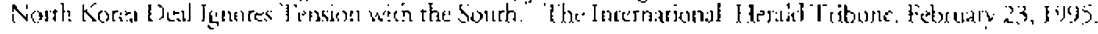


beat the cost, South Korea should have assumed a far more prominent position in the ralks. To have squandered off this opportunity in the haste to "join" the U.S.-North Korea calks was injudicious and unproductive. Injucticious because a little patience would have compelled either the United States or North Korea eventually to approach South Korea for financial support, thereby complerely changing the complexion of the latter's stans. Similarly, unproductive because South Korea's resort to "voluntarism" - that is, to pay-ultimately failed to secure a greater voice for $S$ suth Korea.

Since the United States and North Korea have reached as agreement in Kuala Lumpur in accordance with the conditions of the implementation of the Geneva accord, the focus of talks tended to shift more toward the question of replacing the armistice system with a more permanent arrangement. In a news conference held in Kuala Lumpur, North Korean chicf negotiator, Kin Kye-gwan, made plain his govemment's desire to resolve the state of hostility between Byongyang and Washington in order to ensure the smooth implementation of the reactor project. Again, the key question raised was to what extent South Korea night be a part of this next area of major discussions. Would South Korea be sidelined again in the armistice talks that are likely to have an even more direct impact on the future of South Korean security? Ciuld South Korea afford to sit idly by while its chicef adwersary makes decisions for South Korea under the pretext of creating a wider peace for the Korean poninsula?

Most people are in agreement that the armistice treaty of 1953 is an anachronism that needs to be replaced by a more comprehensive peace treaty. But they also agree that with the fundamental U.S.-South Korean relationship at stake, South Korea can ill-afford to lose the initravive in determining the outcome of what would be a landmark transformacion. From a four-pary tak involving the United States, China, South Korca and North Korea to a cross-establishment of peace treatios between the United States and North Korea on the one hand, and China and South Korea on the other, a number of proposals have been put forward by scholars and concerned government officials to see to a resolurion that would formally end the Korean War." In all proposals, however, the need to maintain the presence of U.S. forces in Korea is stressed, at least until an alternative peace arrangement can guarantec South Korea's security:"

Anidst growing conkern for South Korea's seemingly deterioraring bargaining position, a few interesting ideas have surfaced to help South Korea take the initiative to berome more assertive in the peace treaty negotiations. Jarticularly interesting is the one calling for South Korea co go on a "diplomatic offensive" by unilaterally declaring, ahead of Pyongyang, the end to the armistice agreement. "The basic objective is to take away

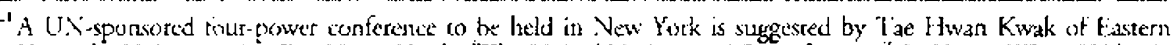
Kentucky Universicy. Sec Tar Hwan Krak, "The Lnited Vatiuns and Recinificarion." In Young Whan Kihl, ed.,

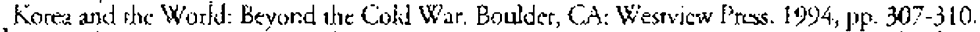

"For timher discuxsion on Sonth Korca's secirity policy, inter-Koreat relations, and the finute tole of the U.S. forces in Korca, sec Jac Hwan Kwak. "The Reduction of U.S. forces in Korea in the Inter-Korean Peace Process."

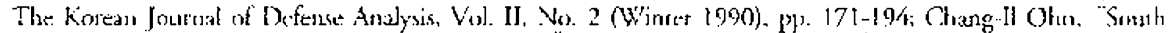
Korea's New Defence P'olicy and Military Srratego." The Korean Journul of Defense Analysic. Vol. VI, Vo.]

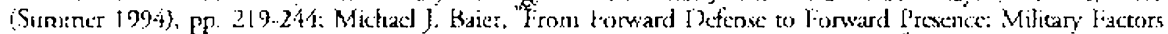
Fullucncing the ROK aud LS Combined Forces in the Appreschinge Linification Era," The Korean fournal of

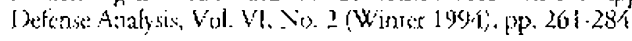


North Korea's "armistice card" so that it would be compelled to deal more directly with the South. In ocher words, since South Korea is not a signatory to the armistice treaty, with this treacy invalidated. North Korea would no longer have the legal basis to exclude South Korea from the new peace negutiations. ${ }^{23}$ This is a rather fresh approach to the armistice issue but not without its pitfalls. First, there is the question of South Korea having the legal basis io take such an action. Can South Korea nullify an agreement that it is not a party to? Assuming that it can, then there arises another problem of a security viciuum that woukd result from a sudden dismantling of an arnistice treaty without first having secured a viable alternative security arrangement. In particular, how can the United States or Sourh Korea justify the continuing presence of U.S. forces in Korea in the absence of the very source of its legirimacy? An ad hoc or even a permanent presence of LN peackecping force has been suggested by some as a possible alternative to U.S. Forces in Kotea. But why do away with a system of peace-- more in terms of U.S. military commitment in Korea ather than the armistice agreement per $\boldsymbol{y} \cdot \cdots$ that has worked so well in prevenring the resumption of war in Korea? Coning on the heels of the apparent failures of UN peacekeeping operations in Bosnia, the argument for $U N$ peacekeeping forces in Korea is nor very convincing at this juncture.

the question is not about whether the amistice agrement should be distrauded or not. Rather, it is about finding an alternative arrangement that could replace the armistice without discupting the securiry balance in Korea. In doing so, a ' $16+2+2$ formula' might be proposed that would deal with the following three questions: First, how might South Korea prevent North Korea from concluding a separate peace deal with the Lnited States that could lead to the withdrawal of U.S. forces from Koreas Second, is there a way to enhance the UN profile in the search for che long-overdue peaceful resolution to the korean contlice And alird, what would be the most effective deterrent against North Kurea's urititary atluenturism?

In the ' $16+2+2$ fornula' the sixteen refers to all the countries that had conrribured milizary forces to the $\mathrm{LNV}$ Command during the Korean War. The first set of two tefers to Russia and China, and the second set of two to South and North Korea. Kather than taking the wsual UN Security Council or the General Assembly approach, the '16+2+2' approach retight be desiralle because it involves only thox nations that had actually paricipated in the Korean War. Having made significant material and human sacrifices during the war, these nations should have strong interest in reaching a peaceful sectlement in Korea. For South Korea, it is particularly important to revive the "collecrive securiry" character of the sixteen-member LN Command for two reawons: First. this would be in

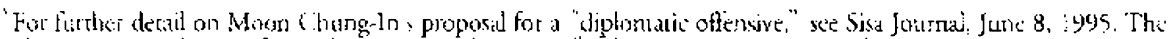

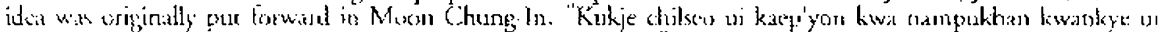

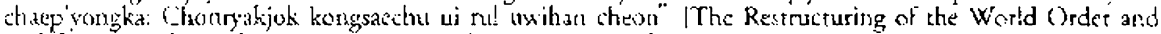

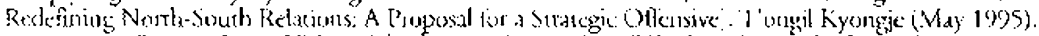

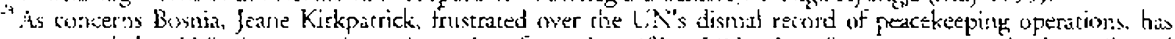

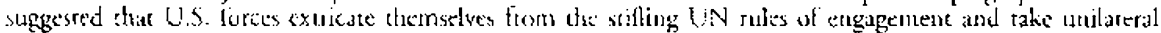

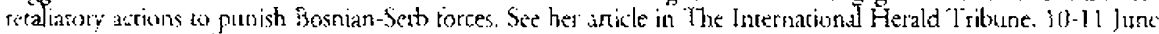

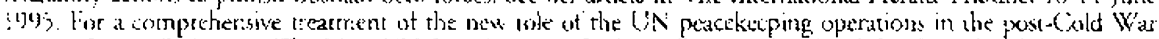

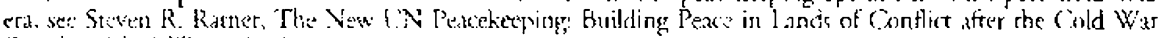

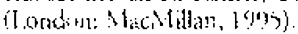


line with the growch in LN activities throughont the world spursed on by the U.S.Soviet (or Russia) cooperation. The UNC having been dominated by the United States since its inception, this would be a good time to redress the imbalance and take on a more genuine UN form. Second. the creation of a more balanced and vibrant UNC would reduce the dangers of the Linited States making a nave decision co deal exclusively wich North Korea on the peace treity issuc. Judging from the way the U.S. behaved dur. ing the Geneva and Kuala I.umpur negotiations with North Korea, this is a prospect that Souch Korea cannot ignore. So to check both North Korea and the Cinited States from making decisions that might nun counter to South Korcan national interest. Seoul could rake initiatives to rekindle the interests of all sixteen nations that have 'earned' their say. in how peace should be maincained in Korca.

Against this backdrop, it is perhaps only natural that the new forum be modelled on the Gencm Conference of 1954. In fact, it may add just the right touch of symbolism to revive the Geneva Conference. The two main principles raised back in 1954 would remain intacl:

1) that any unified Korean government must be based on genuinely free elecrions; and

2) that the authority and competence of the United Nations wo deal with Korea must be rocog-

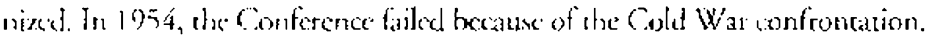

With the Cold War over, the Conference sands a far better chance to survive and perhaps to resolve the Korean question once and for all. One important condition, however, might be added to put the pressure on North Korea. The new condition would entail the stationing of regresentative forces of the UNC in conjunction with existing U,S. forces." A token Russian and Chinese forces might also be invired to consure their full support. It would be preferable: to divide these forces to be stationed in both North and South Korea. Pyongrang will most likely object, in which case, the South Korean government should go ahead to acoommodate the "combined" forces in South Korea alone, that is uncil lyongyang succumbs to LN-sponsored CSBMis, arms control, and ultimately allKored democratic elections. If South Korea is able to take the initiative to bring about such an arrangement the pressure will have been transferted to the North Koreans to respond with posirje steps. Morcover, it would be mose difficult for Norrh Korea 10 con.ccive of another invasion in the face of "collective security" formly ser up in the Sourh. Most importantly, under such an arrangement, South Korea would no longer have to feat the dire consequences of yet another Pyongyang-Washingron agreement, this time of what mighr possibly be a bilateral pace treaty.

It is important to extablish a legitimate institutional structure governing the security issucs on the Korean perninsula. Pacc processos ate less offective, if not mearingless, without a proper institution in place to facilitate them. 'The point about ' $16+2+2$ '

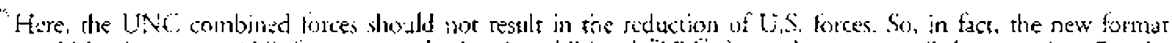

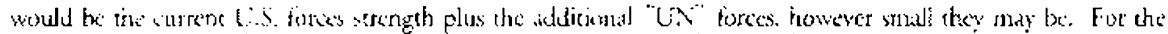

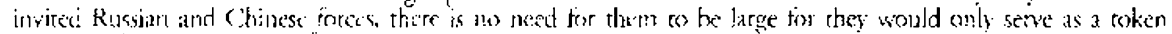

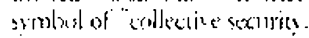


approach is that South Korea, in the absence of a "guarantee" from the United States to defend South Korea's sovereigncy in case of war, should seet altemative arrangements, not as a substitute for a U.S.-South Korea security alliance, but simply as a security safetynet. No one doubts the paramount role the United States plays in maintaining peace in Korea. But who s to guarantee that the United States will never again turn isolationist and propose to wirhdraw its forces from Korea? Where would that leave South Kotca?

'The ' $16+2+2$ ' formula is not perfect. For example there's the problen of involving hoth Russia and China, especially if their troops were to he dispatched to somewhere in Korea, eren in small numbers. Detractors will raise Korean sovereignty issue as well as pointing out the political implausibility of the suggested "mix". But if the arrangement, especially the collective forces concept, is viewed as a major UN effort, rather than as an individual country's ctfort, then much of the politically based misunderstanding could be eliminated. The important thithg to remember is that the arrangement does not discredit or modercut anyone in any significan way: For the United Nations, this is an opportunity to re-establish its lost role in the resolution of the Korean conflict; For South Korea, the arrangenent would be welcome as an added deterrent against North Korea as well as the uncertainty of U.S.South Korean alliance in the long-run: For the United States, the reinforcement of the UN role should be acceptable since the U.S. role and position in Korea remain quire intact. South Koreans still live in fear of North Korea. Yet, in spitc of the passing of nearly five decades since the outbreak of the Korean War, South Korea is still void of a viatic solution wo ensure prace. This has been the domain of the linited States on whom South Korea has relied with extraordinary trust and faith. But the absence of any other effective approach to the Korean question, oher than the raditional relance on U.S. leadership, begs one to ask the question, why not at least try the ' $16+2+2$ astangement?

\section{CONCLUSION}

Almost from the very beginning of the United Nations' creation, the Korean question has loomed large on the agenda of this international organization. First having helped to estiblish the $\mathrm{ROK}$ in 1948, and then having launchad the first collective security effort on belalf of South Korea to repel Communist aggression in 1950, the United Nations has had to deal with this perennial General Assembly issue that has come to be known as the 'Korean question'. For the most part of the Cold War period, the annual debate on the Korean question became both automatic and thetorical. But now with the Security Council paralysis cured to an extent, expectations on the United Nations have increased to formally end the Korcan Contlict. Against the background of dramatic events that have hanged the political landscape of the world, North Korca's triggering of the armistice debate has provided the serting for the IN to reassess its role in Korea. Having created the problem by suspenifing the war some fory-five years ago, the UN should take the responsibility to resolve this problem by, first and foremost, consolidating its ties with 


\section{South Korea.}

Althougta the idea is still formative, this article has proposed one possible alternative the $16+2+2$ formula' - in bringing about a lasting peace on the Korean peninsula. If the United States, South Kotea, and the LN play their respective cards right, the proposed arrangenent may stand as good a chance as any in resolving the Korean question, expecially from a South Korean vantage point.

\section{REFERENCES}

Baicr, Wichael J. 1994. "From Forward Defense to Forward Presence: Military Factors Influencing the ROK and US Combined forces in the Approaching Unification Lra." The Koretry fottrual of Doferse Analysis 6(2): 261 284.

Cha. Young-kon. 1990. "The Furure of ROK-US Military Relarions." In The Knrean Peningula: Irospects for Amni Reductions under Cilobul Detente, cds. Willian J. I aylor, Young-koo Chia and John Q. Blodgett. Boulder, Colo: Westricw Press.

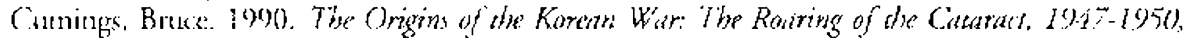
Vol. Il. Princton, N.J.: Princeton I'niversity l'tess.

Curasi, Richard M. 1993. "The Korean War Armistice: Relcvant or Rulic:" The Korean Joumul of Deforse Aratibis S(2): 165-205.

Hastings, Max, 1987. Tha Korean W'tr. London: Mich.lel Joseph.

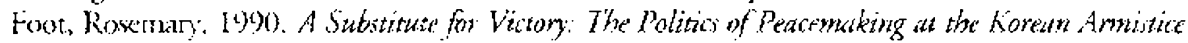
Talk: lthaca. N.Y.: Cornell Liniversigy Press.

Sntermatiotal Herald Tribune. 1995. Jun 1/4.

Kirkpatrick, Jance. 1995. The Sntemationd Therald Tribune. June10-11.

Kontit Ieraid. 1995. May 4.

Korea Herald I'995. May 23.

Kwak, Tac I Iwan. 1990. "I he Reduction of U.S. forces in Korca in the Inter Korean Pace Process." The Koretn fournd of Oefense Anolysin 2) (2): $171-194$.

Kwak, Tae Hwan. 1994. "The United Nations and Reunification," In Korea and the World: Beyond the Cind W'ar, ed. Young Whan Kihl. Boulder, Colo.: Wescview Press.

Macbonald, Callum A. 1')86. Korea: The War Before' listmam. New York: The Free Press.

Woon, Chuner-In. 1995a. "Kukje chikso ui kacp'yon kwa nampukhan kwankyc ai chacp'yongka: Chonryakiok kongsiechu ui nut uwitzan cheon" ["The Restrueturing of the World Order and Redetining North-South Relarions: A Proposal for a Strategic Offensive"]. T"angil Kyongie $5(\mathrm{M}: y): 56.70)$.

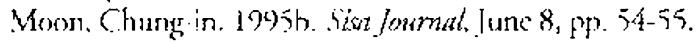

Ohn, Chang-I], 1994. "South Korea's Now Defense ['olicy and Militany Strategy" The Kinean Joumal of Defense Anabsti $\mathrm{s}(1): 219-244$.

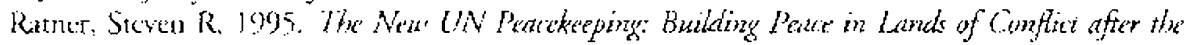
Cold ther. Iondorr: MacMillan.

Shim, Jae Hown, and Nigel Holloway. 1995. "Yanking the Arnistice." Far Eatsten Eionomic Rovew, May 18. p. 1.4-15.

Shiu, Rine sup. Year of Publication. "Nerth Korean Policy cowad the Lnited Stares: Past and Future" In The Chatrging Workh Order: Ponspects for Korad in the Asia Patific Era, eds. Bum Joon l.ec ind Sune Chul Yang. Seoul, Korea: The Korean Association of International Studies.

Korra Fleweld. 1995 . Mardi 19. 


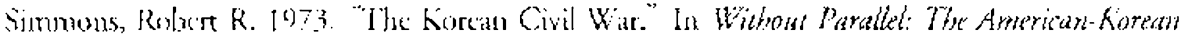

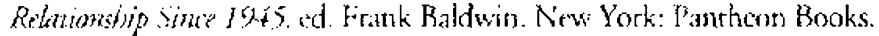

Srone, lsidor F. 1969. The Hidden Fison of the Korean War. 2nd ed. New Yorki Monthly Reriew P'ress.

Tong allow 1995. Nity 4, 5, 11 .

Wolfowitz. Paul D). W995. "lhe Noth Korea Deal Jgnores Tension with the Sourh." The fistemational ferild /ivilune, Febuary 23. 